\title{
第16 回関東農村医学会総会
}

\author{
日 時：平成元年 7 月 9 日(日) \\ 会 場：埼共連ビル（埼玉県大宮市土手町 $1-2$ ) \\ 学会長：佐藤 直義 (熊谷総合病院長)
}

〔特 別 講 演〕

\section{農村の健康問題の変遷と今後の課題}

\section{一日本農村医学会の歩みから一}

千葉大学医学部教授

内田 昭夫

日本農村医学会は，昭和 27 年に結成されたが，厚生 連病院の代表院長による協議から誕生した。その目的 は，農民のための「農民の掞役に立つ」臨床と予防の 一体化を目指寸実学的研究を主眼とする, と第 1 回会 長若月佐久総合病院長はあいさつされた。その精神を 受け継いで今日（本年は第38回）に至っている。本学 会の特徵は, 実学にあるので, 1) その時代と地域特性 を反映しての今日的課題が多い。2)疾病の診断・治療・ 管理の臨床医学, 農山漁村の保健衛生を問題とする公 衆衛生学, 農業労働を中心とする農業医学の 3 分野を 包括し, さらには, 農学, 農村社会学, 人間工学等の 学術的研究の領域を有している。3) それゆ光, 会員構 成として，医師のほか多くの Comedical staff が参加 している。学会運営に扣いて農協病院等の施設会員と, 目的に賛同する個人会員からなる。4)農水産省・厚生 省・全共連からの研究補助を受けているが, その課題 はまさに，その時代に抢ける主要課題であり，本学会 の進歩に大きな貢献を果している。

第37回までの総会に打ける発表演題は5,000余に及 ぶ。3 分野別にみると, 臨床関連演題が $44.5 \%$, 農村 保健衛生 $33.3 \%$, 農業医学 $22.2 \%$ であり, 発表演題の 推移の特性をみると初期では, 結核をはじめとする感 染症, 寄生虫, 農夫症, こうで, 冷光, 潜在疾病, 早 老, へき地医療など。中期以後では, 八ウス病, 出稼 ぎ, 農薬中毒, 農業機械災害, 婦人の貧血, 循環器疾 患・消化器疾患の管理, 癌の臨床・疫学, 人畜共通疾 患, 最近では, それらに加えて老人保健・看護等が注 目される。

将来の課題としては, 老人の保健福祉, バイオテク ノロジー利用による農業生産と健康問題, 兼業農家の
健康管理, 農薬の空中散布・ゴルフ場散布等の環境污 染と健康, 健康増進を目指した暮しの問題, 後継者問 題等, 疾病対策から農業生産・生活管理, 住民の学習 活動を含めた自主的健康管理の確立などの研究が望ま れる。

\section{〔座長のまとめ〕}

梅原医院

水間 正冬

昭和 49 年 7 月に第 1 回関東農村医学会が設立され, 私が第 1 回の会長をひきうけて以来今回で第16回を迎 え, 埼玉県では 3 回目の開催となった。この時にあた り, 当会の創立当時から指導的立場でもっともご協力 いただいてきた内田教授に特別講演をしていただくこ とができたのはまことに有意義なことであった。内田 教授には「農村の健康問題の変遷と今後の課題一一農 村医学会の歩みから一」」と題して，1時間有余にわ たってきわめてわかりやすい内容の豊富な御講演をし ていただき，会員に多大の感銘を与えて下さった。そ の内容を御紹介すると，まず昭和 27 年 7 月に若月先生 を会長として長野市で開催された第 1 回日本農村医学 会総会の模様について話され, その時の演題は70題に すぎなかったが, 関東地区からは栃木県や埼玉県から の発表があり, 日光市で開催された第 2 回総会では, とくに杤木県からたくさんの演題が発表された。その 後日本農村医学会は年を追らごとに演題数が多くな り, 昨年の第37回総会では330題の多きに達し, 関東地 区では土浦協同病院の発表がきわめて多くなった。こ のよ5に日本農村医学会の経過についてこと細かに話 された。演題の内容も当初は, 感染症, 寄生虫, 農夫 症などが主であったが, ついで農薬中毒, 臨床面での 循環器疾患, 消化器疾患などが多くなり, さらに健康 調査, 健康管理, 糖氺病, 貧血, 栄養, 農業災害など の演題もらえ, 最近では看護婦, 薬剂師, 検査技師, 放射線技師などからの発表も多くなった。つぎに，農 村医学会のもっとも大きな業績である宿題報告, 特別 
報告, シンポジゥム等の内容について詳しく述べられ， さらにまた農林水産省や厚生省の補助研究, 全共連の 委託研究などの内容にもふれ，農村医学会の特殊性に ついて述べられた。最後に, 今後の課題として, 兼業 農家の健康問題, 専業農家の課題, 農村の生活習慣々 健康, 老人の医療々福祉, 環境污染の問題などについ ての技考光を述べられ，われわれ会員の関心を扮招い に高めて下さった。

\section{〔会 員 講 演〕}

\section{1. 急性ガス中毒の 9 名}

取手協同病院

○品田 秀穂, 片岡 直之, 鴆瀬 順二 安部 慎治, 野上 昭彦, 矢内 常人 日ノ下文彦, 服部 光治, 岩本均 湊 志仁, 飯泉 智弘, 椎貝 達夫

急性ガス中毒における画像, TBLB, BAL 所見等の 報告は少ない。今回われわれは町工場にて発生したガ ス中毒患者 9 名を経験したので報告する。患者は 32 才 から41才の女性で開放型ストーブを暖房に使用して複 写機の組立作業を行なっていたところ，作業開始後約 2 時間より上気道刺激症状が，ひきつづいて発熱と呼 吸困難が出現した。来院時血液ガス分析の悪化, 胸部 単純・CT 写真上微細な粒状影が出現し, 尿タンパク潜 血も伴った。 $\mathrm{O}_{2}$ 吸入とステロイドパルス療法を行な い, 後遺症を残すことなく数日で改善した。ガス吸入 数日後の BAL 上は好中球リンパ球の増加がみられ, TBLB 上は hyaline membrane の出現を含む alveolar damage がみられた。ストーブの燃焼試験では特定 ガスの検出はされなかったが, 部品洗浄液としてフロ ンリルブが使用されており，これが揮発してストーブ の炎により塩化水素・塩素・ホスゲン等に分解され, それらが障害をもたらしたと考光た。

\section{2. 急性呼吸不全と血小板減少を来たした恙虫病の 1} 例

杤木県厚生連塩谷病院

○小林多鶴子, 海老原哲郎, 潤間 隆宏

廣島 健三, 滝沢 弘隆

獨協医科大学第三内科

奥山 明彦，榎原 英夫

症例：47才, 男性。主訴：発熱。家族歴, 既往歴に
特記すべきことなし。現病歴：昭和63年 6 月 26 日, 突 然 $39 \sim 40{ }^{\circ} \mathrm{C}$ の発熱があり近医を受診したが解熱せず 7 月 2 日同院入院となった。入院時，全身に米粒大の発 疹を認め急性感染症の診断のもとに抗生剂投与を受け たが軽快せず，著明なリンパ球怙よび血小板減少を認 めたため, 精査加療目的に当院へ転院となった。入院 時検査成績では, 血小板数 3 万と著明減少し, 凝固 系検査では, FDP 中等度上昇と赤沈の遅延が認めら れ，末梢血リンハ球数 $312 / \mathrm{mm}^{3}$ と減少していた。この 病態がなんらかの感染症に伴ら DIC あるいは血液疾 患である可能性を考えて骨髄穿刺を行なった結果，悪 性細網症が疑われ，また入院翌日より認められた急激 な呼吸不全は，これに合併した日和見感染と思われ ST 合剂の投与を開始した。しかし，その後の検索によ り恙虫病と判明し minocycline の投与により治癒し, 血小板減少は反応性細網症と判明した。

\section{3. 反復発症した閉塞性細気管支炎・器質化肺资 (BOOP) の 1 例}
埼玉県厚生連幸手総合病院
○沈士栄, 斉藤 幸雄, 渡辺 恒家
飯嶋 淳滋, 久保 貴史, 三上繁
溙原 昌人

症例は73才男性。主訴は微熱と軽度の咳, 痰。胸部 X線写真にて, 右上中肺野に広範な浸潤影が認められ た。抗生剤を投与するも, 陰影が右下肺野, 左下肺野 へと移動し, 広がった。TBLBにてBOOP と診断さ れ,プレドニンを毎日 $40 \mathrm{mg}$ より投与を開始し, 陰影が 素早く消退した。その後プレドニンを漸減し, 約 4 か 月半後, 毎日 $2.5 \mathrm{mg}$ になった時点で左上肺野に再発し た。発症して 6 日後施行したTBLBにて, 肺胞腔内に fibrin, 少々の膠原線維, 出血, 大単核細胞と線維芽細 胞などが認められるが, 好中球の滲出がほとんどなく, 明らかにこれは普通の細菌性肺炎の遷延化による器質 化肺炎ではないことが分かった。再びプレドニンを40 mg に増量したら, 陰影がまた素早く消退したが, 約 8 か月半後, $5 \mathrm{mg}$ まで減量した時点で, また右上肺野に 再発した。今回は陰影が消退した後, 目下 $10 \mathrm{mg}$ で維持 中である。ステロイド維持療法の必要性およびその維 持量の検討が必要と思われる。

〔座長のまとめ〕 $(1-3)$

千葉大学

野尻 雅美 
1：複写機の部品組立工場で開放式の石油ストーブ を使用中に，集団急性ガス中毒が発生した。16人中 9 人に中毒症状が発生, 内 8 人が入院した。もっとも重 症な例について臨床経過が示された。原因については その後の燃焼実験により,フロン113がストーブの炎で 分解され, 数種の有毒ガスが発生し, これらの相乗作 用によることとした。重症例にはステロイドパルス療 法が奏効した。滝沢（塩谷病院）よりホスゲンの発生 状況と関与の有無について質問があった。また沈（幸 手病院）から気管支の変化について質問があり, 非特 異的変化が見られたとのこと。従来よりこの種の報告 は少なく, 真の原因を求めて, 疫学的, 実験的にさら に詳細な検討を期待したい。

2:多彩な症候, すなわち DIC, 悪性細網症, カリ 二肺炎などを伴った恙虫病の症例報告で, 臨床的に minocycline で急速に改善, 蛍光抗体法により Gillian 株での IgM 型, IgG 型の抗体価の有意な上昇により確 定診断された。近時, 流行している新型恙虫によるも のと思われるが, 通例の軽症例とは異なり特異な経過 を示した重症例で, 鑑別診断上, 示唆に富む報告であっ た。漆原 (幸手病院) から, 恙虾病の肝障害について 質問があった。

$3:$ 本症は1985年に病理学的な一つの疾病概念とし て確立され，その後，各方面から報告がされている。 臨床的特徵は抗生物質無効, ステロイド有効な多発性 肺炎で, 最終的には病理診断のみにて可能である。本 報告例は臨床的には典型例だが，組織所見についてフ ロアから質問があり,本例では問題ないとしながらも， TBLBによる細気管支レベルの組織診断の可能性に ついて，意見の交換がなされた。ステロイドの減量中 に再発があり, 維持量の決定が慎重にされる必要があ る。

以上 3 題，與味深い貴重な報告であった。時間の関 係上十分討議ができなく悔やまれるが，いずれ正式な 報告を期待したい。な招，第16回関東農村医学会抄録 集にはデータを示しやや詳しく報告されている。

\section{4. 腹腔鏡検査による日本住血吸虫症の診断}

社会保険・山梨病院

○川村 雅枝, 前田淳, 井口孝伯 飯田 龍一, 小俣 好作

最近 8 年間に社会保険山梨病院において腹腔鏡直視 下肝生検を施行した 362 例のらち生検組織中に日虫卵 を検出した 60 例 $16.6 \%$ を対象に日虫症の診断と検出率
について検討した。組織像は、日虫卵を認める以外正 常 $3 \%$, 日虫卵とそれに伴う線維化 $23 \%$, 日虫卵によ る線維化とウィルスまたはアルコールによる変化 25\%，ウィルスをたはアルコールによる変化の中に少 数の日虫卵 $49 \%$ であった。腹腔鏡所見から日虫症を診 断できたのは56例で, 診断率 $93.3 \%$ であった。診断の 根拠別には小斑点状の黄色苔 $50 \%$, 星芒状から線状な いし網目状さらには地図状の黄色苔66\%, 肝表面を広 範に被う白苔 $12 \%$, 亀甲型の肝表面 $17 \%$, 日虫症性の 変化なし $7 \%$ であった。

\section{5，農協健診にみられる農薬中毒の実態}

土浦協同病院農村健康管理センター

○北沢 直子, 片岡 清美, 村沢 ふ2 片根 昌恵, 片山 聖子, 田谷 利広

国立公害研究所 田村 憲治

当院では，農協健診時「農薬中毒調査」を実施して いる。今回昭和 63 年度, 症状があり治療をうけた者, 男26名, 女54名について詳細な調査票を配った結果, 回収率が $55 \%$ あり, このうち記載事項不備のため, 無 効回答率が $61 \%$ となったので, 該当者 17 名についての 報告をする。

年令別にみると 50 才代が半数であり, 女性が 7 割を 占める。もっとも多い症状は，「皮膚がかゆい」ついで 「頭痛」であり, 手の湿疹, かゆみで治療している者 が大部分を占める。通院例は 15 名, 入院例 1 名(湿疹) であり, 昭和 58 年より通院治療中の者が 1 人いる。服 装は手袋使用者 8 割であるが, 防水用手袋使用者が 4 割のみであり,やはり完全防備が必要である。

本年度からは集団健診時の問診に扔いて，中毒を認 めた者に対しては，詳細に聞さとりを行ない，中毒症 状の害態を明らかにするとともに中毒発症予防につと めている。

\section{6. 茨城県南部におけるペースメーカー植込みの現状 一とくに高令者における特徴とその長期効果一}

土浦協同病院循環器内科

青沼 和隆, 家坂 義人, 田中 千博 徳永毅, 雨宮浩, 小橋 和彦 井能 克吉, 阪本 貢, 藤原 秀臣

近年, 生理的ペーシングの開発に伴い, ペースメー カ一植达みの適応が拡大している。そこで, 当院に拉 けるペースメーカー植込み患者について, 患者背景, 
その適応ならびに長期経過観察の結果について報告す る。対象は過去 3 年間に打けるペースメーカー植込又 患者133例 (年令は28 94才；平均68才) で，75才以上 の高令者植込み例は 40 例（30\%）であった。植込及適 応は洞不全症候群58例, 房室ブロック43例, 徐脈性心 房細動 24 例, その他 8 例で, 植込みペースメーカーは DDD47例，AAI29例，VVI57例であった。合併症は創 部感染 1 例, 創部出血 6 例, 発熱 1 例, 血栓塞栓症 1 例などがみられたが，高令者に合併症が多い傾向はな かった。また高令者に扔いても Quality of life の向上 が認められた症例が多く, 生命予後のみならず生活予 後 (Quality of life) の面からも, 高令者に怙けるペー スメーカー植込みの有用性が示された。

\section{〔座長のまとめ〕 $(4 \sim 6)$}

相模原総合病院

石井 昭郎

4: 腹腔鏡検查に上る日本住血吸虫症(以下日虫症) の診断上の意義について，述べたものである。1981年 〜 1988年の 8 年間に腹腔鏡下で実施された肝生検組織 の362例中, 日虫卵検出の60例について検討している。 それによると, 組織中少数の日虫卵の 42 例, 日虫卵に よる線維化とウィルスまたはアルコール性変化15例, ウィルスまたはアルコール性変化が主体で日虫卵少数 29 例であった。また日虫卵検出60例中, 腹腔鏡で日虫 症と診断されたもの56例, とくに小斑点状の黄色苔の 又認められたもの 30 例であるとし, 腹腔鏡の意義を強 調した。討論のなかで, 画像診断における腹腔鏡の位 置について, 演者らは, 超音波による検出率 $60 \%, \mathrm{CT}$ では40\%であるとし，とくに黄色苔が直接みられる点 で，腹腔鏡は侵襲を加える点を考慮しても，その有用 性は疑いのないものであると述べている。

5 ：農協の集団健診時に，農薬中毒調査を加兄て, 治療したと回答した者に, 詳細な調査表を送付した結 果をもとに分析したものである。それによると，送付 した者 80 名中, 回収者は 44 名, 万ち記載不十分, 当該 年度以前の治療歴などの理由により除外された者 27 名 で, 残る治療歴の判然としている者17名について検討 している。年代では 40,50 才代に多いのは当然と思わ れるが, 皮膚蛍痒感を筆頭に, 気持の悪さ, 頭重, だ るさ, 顔が赤い, 眼痛, 発熱などの症状を示している。 発症原因として, 農薬散布直後に起こることがもっと も多いが, 他に, 散布以外によるものもある。発生要 因として, 防備不充分, 不注意, 長い散布時間, 知識 不十分，機具不良などで，知識と注意力があれば多く
は防げたと思われる。また調査表による方法は，意志 の疎通が十分ではないことも多く，今後さらに工夫を 加穴ての報告に期待するものである。

6 : 茨城県南部地域に扮いて, 過去 3 年間に, ペー スメーカー植込久を行なった患者を75才以上のI群 と，それ以下のII群に分けて検討したものである。そ れによると I 群の占める割合は $30 \% ， 40$ 例であり， II 群は70\%，93例であった。合併心疾患（高血圧性心疾 患, 虚血性心疾患, 心弁腹症, 拡張型心筋症など) は I 群に多いが，植込みを必要とした臨床的不整脈は I 群，II群間に差はなかった。ただI群に打いては AAI 例が少なく, VVI 例が多くなる傾向があったとしてい る。また I 群, II 群ともに植込及後自覚症の改善のみ られること, しかも I, II群間で有意ではないがより I 群で高率であること, さらに植込久後の合併症には I, II群とも有意の差のないことより, 高令者におけ るペースメーカーの植込みは, 生命予後のみならず, 生活予後にも有用であると述べている。

\section{7. 当院における胃集検（63年度）についての若干の 考察}

埼玉県厚生連熊谷総合病院健康管理部

○松井 七, 羽鳥 年男, 棚沢 伸浩

田口 順子

埼玉県厚生連では，昭和48年より農業者健康管理推 進事業 $(\mathrm{A}$ グループ)を開始した。今回は上記 A グルー プに加えて農協役職員 (B グループ) 成人病巡回検診 (Cグループ) などの 63 年度分について胃検診を取り 上げ若干の考察を試みた。

検診方法は 1 次検診は間接撮影で行ない，精密検査 は直接撮影法および内視鏡検査を行なった。

各グループの一次検診受診率は A グループ100\%, B グループ $23 \%$, C グループ $98 \%$ であた。年代別の異 常率は男女とも年代順に増加を示したが，男性の60代 は比較的低かった。男女別では，いずれの年代でも男 性に高かった。また当院で胃直接撮影を受けたものは 1 次検診に対して $1.5 \%$ であり異常率は $42 \%$ であった。 内容は十二指腸潰瘍, 胃炎性変化, 胃潰瘍などで大半 を占めた。また胃内視鏡検查を受けたものは 1 次に対 して $0.9 \%$ であり, 異常率は $72 \%$ であった。内容は胃炎 性変化がもっとも多く, ついで十二指腸潰瘍, 胃潰瘍, ポリープなどの順であった。最後に早期癌の 1 例を報 告した。 


\section{8、検診発見胃癌からみた内視鏡検查の有用性}

社会保険・山梨病院

$\begin{array}{rrrr}\text { 前田 } & \text { 淳, 川村 } & \text { 雅枝, 井口 } & \text { 孝伯 } \\ \text { 飯田 } & \text { 龍一, 小沢 } & \text { 俊総, 小俣 好作 } \\ \text { 草野 } & \text { 佐 } & & \end{array}$

昭和 58 年 4 月から平成元年 3 月までに当院の検診で 発見された胃癌は141例である。発見頻度は内視鏡検查 施行例，延べ32,159例中122例 $(0.38 \%)$ であった。当 院で手術を施行できた 126 例についてみると早期胃癌 が92例（73.1\%）であり，II c 型早期胃癌が圧倒的に 多かった。な拈半数以上が深達度 $\mathrm{m}$ であった。また， 発見方法では92例中 82 例 $(89.1 \%$ ）が内視鏡検查で発 見されていた。発生部位では前庭病変は32例中 31 例 （96.8\%）が内視鏡検査で発見されていた。

内視鏡検査施行状況をみると過去 6 年間で延べ 32,159 例施行しており, 昨年 1 年間では 8,535 例施行し ている。内視鏡検査の選択率は平均 $32.3 \%$ であった。 当院の職員の成人病検診に抢ける内視鏡検査選択率は $71.4 \%$ で啓蒙の点からも注目される数字である。

検診の場に打ける内視鏡検査は早期胃癌, とくに前 壁の病変の発見に有用であった。

\section{9.人間ドックにおける腫瘍マーカーの意義} -1 年間の集計一

社会保険 - 山梨病院
○川村 雅枝, 前田 淳, 井口 孝伯
飯田 龍一, 小俣 好作

1988年 4 月から 1 年間に社会保険山梨病院の 1 泊 2 日ドックを受検した 1,545 名を対象に AFP, CEA，打 よびCA19-9 検查について検討した。腫瘍マーカー それぞれの異常者数は順に 2 例，89例，42例で，その 中に膵藏癌 1 例, 直腸癌 1 例が含まれていた。この 2 例はドック時の腹部超音波検査, 大腸内視鏡検査で発 見されたもので，腫瘍マーカー異常者に対する 2 次検 查で発見された悪性腫瘍はなかった。一方, 1,545例の なかに他に 9 例の悪性腫瘍 (甲状腺癌, 胃癌, 直腸癌, 直腸カルチノイド, 肝細胞癌, 腎細胞癌) が発見され たが、ドック時の超音波検査, 内視鏡検査で発見され たもので, それらの腫瘍マーカーは正常値であった。
〔座長のまとめ〕 $(7 \sim 9)$

土浦協同病院

西村 正信

7 : 熊谷総合病院におけるもっと近の胃集検での成 績を, 農業従事者扣よび農協役職員の各群で解析し, 有所見率は男性が高く，また異常所見は球部之胃角部 に多いことを報告した。さらに，2次検診の成績より 内視鏡検査がより有用であると述べた。

8：人間ドック扣よび成人病検診での胃集検対象者 を胃 X 線検查受診者と内視鏡検查受診者とに分別し 比較検討した成績より胃 $\mathrm{X}$ 線検査に比し内視鏡検查 受診者での胃癌発見率が高いことを報告した。とくに 内視鏡検査での早期胃癌発見率掞よび前壁病変の発見 率が高いことを強調している。検診の場での内視鏡検 査の重要性を指摘した興味深い報告であった。

9 : 人間ドックに拈ける, 腫瘍マーカーの測定は, 悪性腫瘍のスクリーニング法としてある程度有用であ ることを報告した。また腫瘍マーカ一疑陽性者の取り 扱い法について討論された。

\section{0．花園町における腹部超音波集検から}

深谷赤十字病院 内科

○辻 忠男

埼玉県大里郡花園町 (人口 11,615 名, 第 1 次産業人 口22.9\%）に沶いて，私たちは1985年 9 月より 4 年間 にわたりUS 検診を行なった。

被検者総数 1,215 名中, $41.0 \%$ になんらかの所見を認 めた。疾患別では脂肪肝が 149 名, $12.3 \%$ とっとも高 率で50才代で $14.2 \%$ 占めた。以下腎囊胞 $9.6 \%$, 肝囊 胞 $8.6 \%$, 胆石 $5.6 \%$, 胆囊ポリープ4.5\%, 肝内結石 $1.5 \%$, 腎結石 $1.2 \%$, 肝血管腫 $1.2 \%$ の順であった。そ の他 23 例には荤癌 1 名, 転移性肝癌 1 名, 胃癌 2 名が 含まれていた。手術例は胆石症 2 名, 胆石症十胆管拡 張症 1 名, 胆囊腺腫 1 名, 胃癌 2 名の $0.48 \%$ であった。

脂肪肝は 50 才代女で $15.1 \%$ を占めた。この脂肪肝の 比率は都市部に比し明らかに高值であり肥満が原因と 考兄られた。以上より同地区での成人病予防のために は, 50 才代から急増する, 脂肪肝の原因であると同時 に成人病の risk factor としての肥満に対する対策が 重要と考えられた。

\section{1. 当院人間ドックにおける腹部超音波検査の検討}


埼玉県厚生連幸手総合病院

○三上 繁, 飯嶋 淳滋, 久保 貴史
渡辺 恒家, 沈 士栄, 漆原 昌人

昭和 61 年 4 月より昭和 63 年 11 月までの当院人間ドッ クに打ける腹部超音波検查について, 肝・胆・膵所見 を検討した。対象例は男女比約 $3 ： 1$ で男性が多く, 40５0才代が最多であった。有所見率は $37.1 \%$ で男女 差はなかった。疾患別頻度は, 脂肪肝が $22.1 \%$ と最多 で, ついで胆石 $3.9 \%$, 胆囊隆起性病変 $3.7 \%$, 肝囊胞 $3.7 \%$ の順であった。径 $10 \mathrm{~mm}$ 以上の大胆石 32 例につ いては土屋らの分類にしたがって検討したところ, $\mathrm{II}_{a}$ が14例と最多であった。胆囊隆起性病変では径 $5 \mathrm{~mm}$ 以下の小隆起性病変が過半数で, 径 $10 \mathrm{~mm}$ 以上のもの は 3 例に認められた。このらち 1 例は外科的治療を受 け Stage I の乳頭腺癌であった。径 $10 \mathrm{~mm}$ 以上の胆囊 隆起性病変については悪性の可能性を充分に考慮して 経過を追う必要があると思われた。

\section{2. 肝胆膵疾患のスクリーニングを目的とした腹部超 音波検査対象者の選択方法の比較検討}

群馬大学医学部公衆衛生学教室

○小 洋, 辻 忠男, 鈴木 庄亮

既報文献からの各種検查項目の敏感度および特異度 のデータを用い, 腹部超音波検査による荤癌検診の検 查対象者の選択方法の検討および発見㬸癌患者数の予 測を行なった。超音波検査を含めた多段階検診を実施 する場合, もっとも簡便性の低い超音波検査が検診全 体の律速段階となる。そこで 1 次検査によって対象者 数を 1,000 人に絞ることとし, 1 次対象者数を検查項目 の特異度に応じて増減させた。1 次検査として, Ferritin, CA19- 9 または腹部症状の問診を単独で実施し た場合と, 問診後に Ferritin またはCA19-9 検査を行 なった場合の発見荤癌患者の予測を行なった。結果は, Ferritin, CA19- 9 とも偽陽性率が低いので, 1 次対象 者を 4-7万人とすることができ，そのなかから約 1 人の荤癌患者を発見できると予測された。問診後に FerritinまたはCA19-9 検查を行なら二段階方式の 絞り込みでは，100-170万人のなかから20-30人の莢 癌患者を発見できるが，同時に見落としも多くなるこ とが予測された。
〔座長のまとめ〕（10〜12）

群馬大学

鈴木 庄亮

この 3 題はいずれも腹部超音波検査（エコー）によ る疾病の早期発見への応用に関するものである。

エコーは他の検査にくらべて被検者への侵襲が注と んどなく，検查がもたらす身体情報は量質ともに豊富 である。豊富であるために地域の要望でェコー集団検 診が意識せずスタートすることも多い。第 10 席はまさ にその例である。ここでは, 実に多様な臓器レベルの 形態異常が高率にいわゆる健常者集団から発見されて いる。

第11席は対象者が地域の健常者集団ではなく, 人間 ドック受診者である。ここでも多種類の高率の異常が 発見されている。脂肪肝は第10席とくらべて $22.1 \%$ と 2 倍近く高率である。

エコーの問題点は, 熟練した検者を必要とすること, 次のアクションが必要か否かの判定には機能的検査項 目を併せて総合する必要のあること，人数をこなすの に難点があることなどであろう。したがって，多項目 健診の一部としてェコーを入れ込むのは良いことであ るし，第一段のスクリーニングのあとで陽性者にエ コーを実施するといらのも良い方法であろら。この点 で, 第13席は膵癌検診に 1 次スクリーニングのあと 2 次スクリーニングにェコーを実施し, 最適の方式を模 索したものと評価されょう。

\section{3. 茨城県南地域における未熟児・新生児医療 一母体搬送例を中心として一}

土浦協同病院小览科

○清水 純一, 水沢 慵一, 福栄 道郎 神山 潤, 渡部 誠一, 石原 啓志 福田 睦夫

土浦協同病院の未熟児センターも開設 10 年を迎兄 た。この間に当科の未熟児・新生児の生命および神経 学的予後は著しく改善している。その要因の一つとし て近隣の産科開業医の先生方からの未熟児・新生児の 搬送が減少し, “母体内にいる未熟児・新生児”を母体 ごと当院の産科に送ってきていただくいわゆる母体搬 送を受け入れ，治療を行なっている。このように地域 の産婦人科開業医の先生方や院内産婦人科医の協力を 得て未熟児を生ませないように，また万一生まれてし まった場合にはすぐ治療ができるように体制を整えて 
きている。さらに昭和 62 年 7 月より茨城県の新生児救 急医療システムが発足し県南の中核病院に指定された ことより産科への母体搬送例子増え, 新生児・未熟児 の入院数も激増してきた。これらの症例の大半は母体 搬送されて分娩に至った症例で在胎週数の延長を図り 適当な分婏方法を選択することにより生存率の改善を 得た。

\section{NICU 車による病的新生览搬送の経験}

群馬県立小児医療センター

○神辺譲, 小泉 武宣, 武政 礼子

当センターでは開院以来, NICU 車 (新生児救急)

を常備し，24時間出動体制をとってきた。

その救急車の特徵は, 新生児科の専門医が同乗し, 内部には十分な治療機器を装備したことである。

1986年から1988年までの 3 年間の実績について報告 した。総出動回数は, 830 回であった。当センターに搬 送して入院する例がもっとも多かったが，満床の場合 は, 設備のあるほかの病院まで搬送することも多かっ た。また，当センター入院患児を手術や治療等の目的 で, 他の専門病院へ搬送した事例も少なくなかった。

業務開始後 5 年目には, 新生児死亡は著明に改善し, 全国平均より低い死亡率となり, 現在もこの傾向は続 いている。

新生児死亡の改善には, 他の因子の関与も否定はで きないが，NICU 車の活動が扣扔いに寄与したと考光 ている。

\section{Fuji Computed Radiography の妊婦骨盤計測への 応用}

相模原協同病院

$\begin{array}{rrrr}\text { ○樋口 } & \text { 正臣, 望月 } & \text { 愛郎, 松信 晶 } \\ \text { 梶野 } & \text { 徹, 大沢 章吾 }\end{array}$

輝尽性虽光体を用いたデジタル X 線画像法 (Fuji Computed Radiography, FCR）を妊娠後期妊婦の X 線骨盤計測法に応用した。階調タイプ $(\mathrm{GT})$, 周波数 タイプ $(\mathrm{RT})$, 回転量 $(\mathrm{GA})$, 周波数ランク $(\mathrm{RN})$ の 各種パラメータの組合せによる画像の感度, 画質の評 価を行ない, 各種パラメータの適性標準条件の決定を 行なった。

その結果, FCR に打ける骨盤計測の各種パラメータ では, GT はタイプ A, RTをタイプ P, GA は1.6, RN
は2.0の組合せが, 画像の感度および画質の点で最良で あり, 被曝線量では従来の曝射量の $12.5 \%$ の量で十分, 診断可能な画質の像が得られた。このことから，GT， $\mathrm{RT}, \mathrm{GA}, \mathrm{RN}$ の各種パラメータの至適標準条件の決 定により, 従来の X 線被曝線量の $12.5 \%$ にをで曝射量 の軽減ができ, 胎児への被曝の低減ができ, 胎児への 被曝の低減が可能となった。

〔座長のまとめ〕（13〜15）

$$
\text { 筑波大学 }
$$

大貫 稔

この 3 題は, ともに母子保健に関するものであり, とくに13と14は, 未熟児や新生児の緊急医療対策とし ての地域的システムに関する内容で, 新生児死亡率の 低下など母子保健の衛生指標の向上に多大の貢献をな してきた実践的活動に基づいた研究報告であった。

13 : 茨城県に扮いて, 昭和 62 年 7 月に全県を 3 地区 に分けた新生児救急医療システムがスタートし，その 県南地域の中核病院に指定された土浦協同病院小児科 の指定前後の未熟児センターの諸成績を分析比較した ものである。とくに院内外の協力体制によりハイリス ク妊婦の情報収集や，必要に応じての母体搬送例が著 明に増加していることなどが, $1,500 \mathrm{~g}$ 未満の極小未 熟児の著増にもかかわらず，好成績に連っていること が報告された。

$14: 1982$ 年以来 7 年間の NICU 車出動による新生 児救急体制について群馬県立小児医療センターから報 告され, 年間平均 200 回以上の出動による未熟児, 病的 新生児等の治療実績が示された。

24 時間体制で, 搬送用保育器, 新生児監視装置, 経 皮酸素分圧モニタ一, 人工呼吸器, 酸素吸入器, 輸液 ポンプ等を搭載した NICU 車による患児搬送体制の 整備による成果がみられて打り, 前演題とともに, こ のような地域的システムが各地に拡がることが望まれ る。

15：妊娠後期妊婦の骨盤計測にX 線を用いる際に, その線量をきわめて少なくすることを目的に, computed radiography 法を応用し, 階調タイプ, 周波 数タイプ, 回転量, 周波数ランクのパラメーターの組 合せを種々検討し, 従来の X 線瀑射量の $12.5 \%$ の量で 十分な画像の感度, 画質が得られる適性標準条件を示 す報告であった。

このことは胎児への被曝低減で悪影響防止にさわめ て有用なものであり今後の期待が大きいものといえ る。 


\section{6. 熊谷地方における小児気管支喘息について}

埼玉県厚生連熊谷総合病院 小児科

○栃木亮太郎, 石坂 仡

埼玉医科大学小览科

赤坂 徹, 前田 和一

厚生連熊谷総合病院小児科を受診または入院した患 者の5ち，昭和 $61 ， 62 ， 63$ 年の 3 年間初診時または通 院中に初回発作が出現したと考兄られる気管支喘息児 297例を対象として検討したところ，次の結果を得た。

$1 ）$ 昭和 61 年 126 例, 62 年 79 例, 63 年92例の住所別比較 では，市街地対市農村部抢よび市外はほとんど同数で あった。

2) 発症年令別では，2才未満で発症した喘息児の各 年の年に発症した全喘息児の割合は, 昭和 61 年 $34.9 \%$, 62 年 $41.8 \% ， 63$ 年 $45.7 \%$ と増加する傾向にあり，喘息 発症の低年令化が推察された。

3 ）個人アレルギー歴，家族アレルギー歴は $70 \%$ 以上 に認められ，通年性喘息では，55例中個人アレルギー 歴のあるものは 50 例 $90.9 \%$ ，家族アレルギー歴 46 例

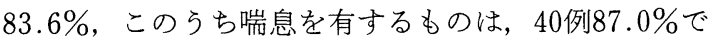
あった。さらに重症例では，17例中個人アレルギー歴 をもつもの 16 例 $94.1 \%$ ，家族アレルギー歴同じく 16 例 $94.1 \%$ ，このうち喘息を有するもの 14 例 $87.5 \%$ であっ た。

$4)$ 各年における喘息児総数に占める重症および中等 症喘息児の割合は注とんど差がなく，重症化傾向は認 められなかった。

5 ) 抗アレルギー薬は, 軽症打よび中等症で $84.6 \%$ に 有効であった。

6 ）喘息児では，ハウスダスト，ダニ等のラスト陽性 率， IgE 值，好酸球数など高値を示した。

\section{7、地域循還器病対策ハイリスク者管理の試み（II）} 一小児成人病検診の場合一

筑波大学社会医学系

筑波大学臨床医学系 土屋 滋, 大貫 稔

筑波大学基礎医学系

柳 久子, 浜口 秀夫

虚血性心疾患のリスクの高い，優性遣伝性高脂血症 家系を効率よく見い出すために，学校検診で見つかっ
た高コレステロール血症児を発端者として，両親をは じめとする家族調查のシステムをつくり，実施した。 学校検診で総コレステロール值 $200 \mathrm{mg} / \mathrm{dl}$ 以上（約 $8 \%$ ）を対象とし，学校・教育委員会などの協力のも 之に，早期空腹時採血（2 次検診）を行ない，2 回と も $200 \mathrm{mg} / \mathrm{dl}$ 以上(約 $4 \%$ ）の小児を高コレステロール 血症児とし, 3 次検診の対象者とした。学校, 自治体, 医師会などの協力下で対象者の家族の参加を求め，早 期採血活か詳細な家族歴聴取，アキレス腱測定など行 なった。

両親ともの受診率 $52.2 \%$ ，両親の総コレステロール 值はコレステロール群に比して有意に高く, $240 \mathrm{mg} / \mathrm{dl}$ 以上の出現頻度は父親，母親ともに対照群に比して有 意に高率にみられた（遺伝性の関与）。

家族性高コレステロール血症 1 家系，家族性複合型 高脂血症 2 家系，その他優性遺伝性高コレステロール 血症の可能性の高い 4 家系が発見された。虚血性心疾 患予防の立場から食生活とともにハイリスク者の管理 指導を始めている。

18. 慢性疾患患者の教育を考える

一慢性疾患を理解させるためのパンフレット活用 を試みてー

埼玉県厚生連熊谷総合病院

○小島 康子，高宮ハル子，腰塚 泉 古郡奈津美，荻野 弘子，藤沼 久枝

慢性疾患は生涯管理が必要であり，慢性疾患患者の セルフケアを養らことは，患者教育の大きな課題でも ある。そこで私たちは患者や患者をとりまく人々が, 今後の健康生活保持に向け具体的な方法を学び習得で きるよらなパンフレットの活用を試みた。

まず，糖尿病，肝臓病，高血圧症のパンフレットを 作成した。そして，アンケート調査を行ない，その内 容について検討した。

その結果, 指導の実際ではパンフレットが指導基準 となり，統一した指導が行なわれ健康教育にも大きく 役立つことができた。また患者の関心度は具体的な食 事内容に高いことが明らかとなり，高令化社会を迎兄 指導の複雑さについて今後の課題となった。

私たちは，健康を維持していくのは自分自身である という積極性を持たせるよう援助していきたい。

〔座長のまとめ〕（16～18） 
神奈川歯科大学

野田喜代一

16：埼玉県熊谷地方に括ける小児気管支喘息の最近 (昭和61～63年)の動向を，外来の初回発作喘息児 297 例を対象として調査検討した。その結果, 多発地域は, 市街地>市外>農村部, 頻度は, 性別では, 男児>女 児，年令別では昭和 61 年には，男女とも 2 才才> 2 才未満 $>6$ 才以上であったのが, 昭和 62 年 63 年と 2 才 未満初回発作が最多かつ増加して, 発症が低年化する 傾向をみとめた。なた，2才末満発症児には重症・中 症者が高率であった。

原因として個人・家族アレルギーの存在が70 $80 \%$ におよび，他方，八ウスダスト，ダ二等の抗原ラスト 値, 好酸球数の高值をみとめた。な拈, 小児喘息治療 の治療について言及した。これに対して，沈士栄（埼 玉・幸手) は, その内容の詳細を質問，演者は抗アレ ルギー剂とアミノフイリン併用の有用性を述べた。

大都市近郊農村の生活変貌の実体を小児喘息をかが みとして把握するという研究が, 将来に期待される報 告であった。

17 : 小児 (学童) 成人病検診の 1 次検診で, 血清総 コレステロール (TCh)が学童の上限值 $200 \mathrm{mg} / \mathrm{dl}$ を超 えた者が1,747名中70名（4\%），その家族検診では， 約 $20 \%$ が親にも高 TCh 血症をみとめた。そこで，これ らの家系についての LDL レセプタ一遺伝子の DNA 分析, その異常を認めなかった家系には, アポリポタ ン白B遺伝子の異常について検討した。その結果，家 系にTCh 血症のある者が18名発見され，その予防抒 よび治療対策を実施した。

今後, 小児高 TCh 血症の自然歴とくに冠硬化症の 進展と虚血性心疾患発症との関係, 両親の疾病, 祖父 母の死因等との関係など, 疫学的研究の発展が期待さ れる報告であった。

18：慢性疾病の管理は, 生涯に拈けるセルフケアが 重要な問題である。そこで, これを入院中に教育し理 解させることを, 看護業務のなかに位置づける試みを 実施してみた。疾病としては糖尿病, 肝臓病, 高血圧 症とし,「健康な明日への 1 ページ」と題するパンフ レットに, 患者が日常実行すべき生活指導内容をわか りやすく, 簡条書とし, 患者, 家族, 面会人に配布し, 患者の個別指導も実施した。その後のアンケート調査 の結果, 以上の方法は好評であったが, とくに食生活 に対する具体的な内容に関心が大であった。他方，本 法によって看護婦間に統一のとれた指導ができる，家 族をふくめた健康教育にも役立つといら利点があっ た。大貫稔（筑波大）は，個人個人によって相違する
運動量などについての指導内容について質問, 演者は 看護の領域と立場とを問題とする旨を答えた。

今回実施された看護婦を主体とする患者教育の方法 は，医師主体よりも，生活に密接したレベルで実施可 能であるから，展開の方法と内容とにいっそうの工夫 を積重ねて, 看護業務として体系化されることを要望 したい。

\section{9. 当院における老人骨折の検討}

\section{上都賀総合病院整形外科 \\ ○矢作 龍二, 大井 利夫, 大西 正康 山越 弘明, 大河 昭彦, 山口潔}

昭和 59 年 4 月より平成元年 4 月までの間に，当科に 扣いて診療した65才以上の骨折患者439例（男148, 女 291例）のべ486骨折（男168，女318骨折）について検 討し報告した。骨折発生頻度は, 女性のほうが男性よ り高く, 高令になるほど高率になる傾向が認められた。 骨折部位は, 体幹・下肢・上肢の順に多く, 胸腰椎圧 迫骨折・大腿骨頸部骨折 -上腕骨頸部骨折・前腕骨遠 位端骨折が多かった。受傷原因は, 転倒・軽い労作・ 原因不詳等の比較的軽微な外力によって発生したもの が多く, 胸腰椎圧迫骨折・大腿骨頸部骨折に执いて著 明であり，女性ではその傾向がより顕著であった。鎖 骨骨折・下腿骨骨折・頸椎骨折等は, 男性に多く, 自 転車やオートバイによる事故など大きな外力が原因と なっているものが多かった。老人の代表的骨折のなか では, 大腿骨頸部骨折の受傷時年令が有意に高く, 骨 粗鬆症との深い関連性が示唆された。

\section{0. 安房郡市における総合検診の成績について（第 4 報）}

安房医師会

○青木 謹, 西川 義明, 穂坂 博明 鈴木 雅夫, 本位田恭介

安房医師会病院

千葉大看護学基礎保健学講座

野尻 雅美, 中野 正孝, 桂 敏樹

安房医師会で行なっている総合検診のうち, 昭和62 年度の検診結果により血圧, GOT, GPT, ヘマトク リット，血清総コレステロールなどの測定值，検査值 について，季節による変動を検討した。性別，年代別 
に検診実施時期と検査データとの関係を検討した結 果，血圧は 7 月から 9 月にかけての暑い時期はやや低 く，4月から 6 月と10月はやや高い傾向を示した。 8 月に実施した三芳村は高くなっているが，地域差と考 えられる。GOT, GPT は 6 月， 7 月抢よび10月にやや 高く, 8 月 9 月にやや低い傾向を示した。 7 月中旬の 富山町, 10 月下旬の富浦町は突出して高く, 季節変動 というょりも昨年報告したごとくに地域特性とした方 が考学やすい。へマトクリットは男では 6 月以降やや 低い傾向にあり，とくに 8,9 月は低值を示した。血 清総コレステロールは年代別, 性別に変動が激しく, 季節変動は明らかにできなかった。

\section{1．高令農業従事者の健康調查}

土浦協同病院農村健康管理センター

$\bigcirc$ 田谷 利光, 篠崎 毅, 真家 徹 湯原 久之, 中田 恭子, 斉藤 景子

昭和63年度農協健診受診者のうち，65才以上の男性 101 人，女性 153 人の健診結果について報告する。総合 判定成績では健康者は男 15 人, 女 14 人であり, 要注意 者は男 19 人, 女 31 人, 要精検者は男 19 人, 女 16 人, 有 病者は男 48 人 $(48 \%)$ 女 92 人 $(60 \%)$ である。農業従 事者の高令化に伴い, 高令受診者がふえているが, そ の有病率は $55 \%$ に及んでいる。

主要疾患としては男女とも高血圧症がもっとも多 く, 35\%に達して抢り, 心臟病も16\%をしめ, 現在治 療中のものが多かった。その他, 男では消化性潰瘍, 女では筋骨格系疾患が多く, また, 肝障害は男女とも 18\%にみられた。

女では高コレステロール者も多かった。

加令に伴い検查測定值が上がるもの, 下がるものが あり, 個人差も大きく, 合併症も多いので, 従来どお りの正常值をあてはめることは誤りを扎こしやすい。 したがって血液検査成績は加令に伴ら年令別の基準值 を設定して対処すべきものであると考学る。

〔座長のまとめ〕（19～21）

\section{上都賀総合病院}

大井 利夫

19：上都賀総合病院で治療した老人骨折例につき, その臨床的背景を統計的に調査報告したものである。

人口の高令化が進むなかで, 老人の骨折例が増加し て打り, その原因として骨粗鬆症との関連が強く示唆
されている。骨折を予防するためには，加令による運 動能の低下とともに骨の脆弱化をいかに防ぐかが焦点 となっていて，かかる意味を含めて報告例と骨粗鬆症 との関係や, 血液学的検討の必要性, 多数回骨折例の 共通因子などにつき質疑発言がみられ，向後のさらな る検討課題のいくつかが明らかにされた。

さらに，老人の下肢骨折に随伴する歩行能の低下や 痴呆の進行などについても, 社会医学的側面を含めて 幅広い検討が必要と考光られる。

20 : 安房医師会を中心とした千葉県安房郡市の総合 検診事業は，長年にわたりその実績を高めてきており， 今回は第 4 報として，検診実施時期別の季節変動につ き検討し報告された。

検診項目のらち最大血圧, GPT, ヘマトクリット， コレステロールにつきそれぞれ季節变動の有無, 男女 差, 地域別特性を調べ考察が加兄られたが，なかでも 最大血圧での三芳村, GPT での富浦町については鋭い 質問がみられ，異常値と有病率との関係や食生活およ び過労との関連などさらに解決さるべき問題が浮きぼ りにされた。しかし，演者のいらごとく，検診を開始 した 10 年前に比し脳血管疾患による死亡率が約 $7 \%$ 減 少したことは，検診事業の大きな成果として評価され るであろう。

向後のさらなる発展が期待される。

21 : 土浦協同病院農村健康管理センターでの昭和 63 年度農協健診受診者のうち，65才以上者の健康診断成 績を検討したもので, 調査年が 1 年間とはいえさまざ まな問題が提起された。

とくに，いわゆる健康者が $11 \%$ に過ぎずなんらかの 有病者が $55 \%$ に及ぶことは, 農業従事者の高令化に 伴って高令者健康管理の重要性が強調される。さらに, 各種血液検査成績について, 加令に伴い平均値が変動 することは，演者の指摘するごとく基準值の設定に一 考を要することを示唆している。正常值と年令別基準 値の差異や検査值の病的なものとのとらえ方など, 高 令者健康管理活動を進めるら劣後解決さるべき課 題を残しているといえよう。

22. 心血管機能指標および血液栄養指標による健康水 準の設定について

銀座内科センター診療所

○大野, 知俊, 岡田 芳子, 高地 利枝

網元 愛子

神奈川歯科大 内科

野田喜代一, 関 博人, 金山 正明 
簡易心機図心血管機能指標抢よび血液栄養指標のう ち, 加令と相関が高い指標をとりあげて、健康成人女 性を対象として健康水準の設定をこころみた。

心血管機能指標のうち, 年令ともっとも相関の高い 指数は末梢抵抗指数 $\mathrm{RP}=\mathrm{u} / \mathrm{RS}$ で, $\mathrm{r}=0.983$ であっ た。他方, 血液栄養指標のらち, 相関の高い指数は $\mathrm{TCh} / \mathrm{Alb}$ で, $\mathrm{r}=0.960$ であった。そこで, 末梢抵抗指 数の RP と血液栄養指標の $\mathrm{TCh} / \mathrm{Alb}$ のベクトル $\mathrm{x}=\left[(\mathrm{TCh} / \mathrm{Alb})^{2}+(50 \mathrm{u} / \mathrm{RS})^{2}\right]^{2 / 2}$ 算出し, あ らためて年令との相関を算出してみた結果, $\mathrm{r}=0.986$,

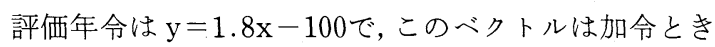
わめてよく相関して変動することをみとめた。よって, 暦年令 $\mathrm{Y}$ と比 $\mathrm{Z}=\mathrm{y} / \mathrm{Y}$ は老化度玉たは健康度 （HGI）を示す指数と考光てよいはずである。

以上から，心血管機能指標 $\mathrm{RP}=\mathrm{u} / \mathrm{RS}$ と血液栄養 指標 $\mathrm{TCh} / \mathrm{Alb}$ のベクトルを用いる健康度指数

（HGI）は臨床においても集検においても有用性の可 能性が高い方法であると考党られた。

\section{3. 高令者の死亡に関する研究 一千葉県下 3 市町村の比較からー}

千葉大看護学部基礎保健学講座

○桂 敏樹, 野尻 雅美, 中野 正孝 順天堂大学浦安病院

千葉市保健所

館山保健所 高谷真由美 稲田 正實 安藤由記男

死亡票を資料として主要死因別に死亡の場所などに ついて千葉県 3 市町を比較・検討した。その結果, 主 要死因をみると, 総数では千葉市は悪性新生物, 心疾 患, の順に, 丸山町は脳血管疾患, 老衰の順に, 天津 小湊町は脳血管疾患, 心疾患の順に多い。死亡の場所 をみると，千葉市では施設内が多く，丸山町では自宅 が多く, 天津小湊町では施設内と自宅活ぼ同数である。 主要死因別に死亡の場所をみると，千葉市では老衰以 外は施設内が多い。丸山町では老衰, 脳血管疾患, 心 疾患に自宅が多く，悪性新生物でも $40.4 \%$ が自宅であ る。天津小湊町では老衰, 心疾患に自宅が多いが, 脳 血管疾患では施設内と自宅は注ぼ同数で, 悪性新生物 では $86.4 \%$ が施設内であるなどが明らかとなった。

〔座長のまとめ〕（22〜23）

全共連

真島 三郎
$22 ：$ 血行動態指標と血液生化学検査值に関し, 年令 による変化を観察したもの。質疑はなし。座長コメン トとして各年令群の平均值について相関をとっている ので高い相関係数が得られている。パラメーター間の 相関は普通は個体ごとにとり, 係数は低くなるであろ 5。

23：千葉県内の代表的 3 地区に捛ける高令者の死亡 の比較。取手協同病院の椎貝より丸山町と天津小湊町 の悪性新生物死亡例の自宅死亡に差が大きい理由につ いて質問あり，一方に大きい病院があることも一因か といら答である。同質問者は病院死亡を容認ないしす すめる立場をとりたいとの意見であった。座長コメン ト：3 地区は死因に関しても典型的で興味がある。若 年者を加党て年令との関係をみるのも興味があるだろ 万。

\section{4. 総合病院精神科における長期入院患者}

\section{上都賀総合病院}

衛藤 進吉

上都賀総合病院精神科の昭和 63 年度入院件数 (169 件)のらち，精神分裂病が圧倒的に多く95件 (56.2\%) を占めた。平成元年 4 月 1 日現在の閉鎖病棟入院患者 の $53.7 \%$ (43名) が在院期間 5 年以上であった。これ らの症例を対象として, 長期在院化の要因を医学的側 面と社会的側面から分析・考察した。

長期在院化をもたらす医学的要因として，(1)疾患そ のもの, (2)入院回数, (3)問題行動の有無があげられる。 疾患別には精神分裂病が圧倒的に多く, 10年以上の在 院患者の $92 \%$ （23名）を占めた。

社会的要因として, (1)親の有無, (2)同居者, (3)結婚 歴などがあげられる。精神障害者の社会復帰に重要な 因子である, 患者・家族関係が長期在院患者ではそこ なわれている。開かれた精神医療のシステム確立のた めに, 総合病院精神科は重要な役割を果さなければな らない

\section{5. インドネシアの農業一家族生活と結婚一}

群馬大学医学部公衆衛生

○鈴木 庄亮, 小山 洋 イダ・F・リファイ

インドネシア共和国の西ジャワ農村の一集落（74世 帯 330 人)に住み込み, 児を産育する基礎である農家の 